\title{
Lined Canister
}

National Cancer Institute

\section{Source}

National Cancer Institute. Lined Canister. NCI Thesaurus. Code C96143.

A round container that has an inner layer of a material different from what the canister is composed of. 